\title{
The Socio-economic Status of Cotton Farmers and their Attitude Towards Pesticide Use
}

\author{
Almaszabeen Badekhan ${ }^{1 *}$ and K. Uma Devi ${ }^{2}$ \\ ${ }^{1}$ Department of Agricultural Economics, University of Agricultural Sciences, Dharwad, Karnataka, India \\ ${ }^{2}$ Department of Agricultural Economics, Agricultural College, Bapatla-522101, Andhra Pradesh, India \\ *Corresponding author: almaszabeen@gmail.com
}

\begin{abstract}
Cotton accounts for the maximum share of pesticide consumption. Over the past decade, the perplexities in pest management intensified more insect species developing resistance to insecticides which was a consequence of excessive use of insecticides on the crop. For the study, multistage sampling procedure was adopted to select the respondents. Twenty cotton farmers from each village were post-stratified into small, medium and large farmers proportionately making a total sample of 120 . The total costs as well as returns incurred were highest for large farmers as compared to medium and small farmers, but pesticides cost was more in case of small farmers. Around 54 farmers (45\%) had spent ₹ 4500 to ₹ 5500 per ha for pesticide application. Most of the farmers do not know how to read literature on pesticide containers. It was astonishing to notice that 73.33 per cent of the farmers were exposed to or not using protective masks/coverings during pesticide application and farmers were found careless in handling pesticides.
\end{abstract}

Keywords: Attitude, costs, pesticides, returns

Pesticides have played a key role in providing reliable supplies of agricultural produce at prices affordable to consumers, improving the quality of produce, and ensuring high profits to farmers. Many studies have raised concerns about health risks from exposure of farmers and from non-occupational exposure of the population to residues found in food and drinking water. About 19.4 per cent of the respondents had experienced negative side effects on health after handling pesticides. Most of the respondents are aware of pesticide-related symptoms and possible routes of absorption during application of pesticides. Farmers make only shortterm assessments of pesticides and spray these chemicals without taking proper protective clothing (Shetty et al. 2011).

India is the thirteenth largest exporter of pesticides. Approximately 50 per cent of the demand comes from domestic consumers while the rest goes towards exports. While the domestic demand is expected to grow at 6.5 per cent per annum, exports are estimated to grow at 9 per cent per annum during the same period. The increased damage to crops from pests and subsequent losses poses a serious threat to food security and further underscores the importance of agrochemicals. The most recent example is the large scale whitefly infestation of $B t$ cotton crop in North India last year. Due to this, cotton area in Punjab \& Haryana has declined by 27 per cent to 7.56 lakh hectares, as farmers shifted to other crops after incurring huge losses (Agro chemical report, 2016). The usage of pesticides in Korea and Japan is $6.6 \mathrm{~kg} / \mathrm{ha}$ and $12.0 \mathrm{~kg} / \mathrm{ha}$, respectively, whereas in India, it is only $0.5 \mathrm{~kg} / \mathrm{ha}$. Globally, the pesticides cover only 25 per cent of the cultivated land area. The three most commonly used pesticides are $\mathrm{HCH}$ (only gamma-HCH is allowed), DDT and Malathion, and these account for about 70 per cent of the total pesticide consumption. Despite development of newer pesticides, these old generation and obsolete pesticides still remain the choice of small farmers because they are cost-effective, easily available and 
display a wide spectrum of bioactivity (De et al. 2014).

India is the largest producer of cotton in the world producing 26.8 million bales and accounting for about 26.5 per cent of the world cotton production (NASS USDA, 2015). It has the distinction of having the largest area (11.7 million hectares) under cotton cultivation in the world. The Indian textile industry contributes about 11 per cent to industrial production, 14 per cent to the manufacturing sector, four per cent to the GDP and 12 per cent to the country's total export earnings (IBEF, 2014).

Cotton pest management was particularly affected due to insecticide resistance, which was a consequence of excessive use of insecticides on the crop. Insecticide resistance rendered insecticides ineffective, thus increasing the need for repeated applications, wastage of resources and consequent environmental pollution. Cotton leafhopper was found to have developed resistance to various insecticides viz., Malathion, Dimethoate, Oxydemeton Methyl and Phosphamidon (Singh and Jaglan, 2005). Resistance in leafhopper population against organophosphates has also been reported by Sagar et al. 2013. Mirid bug has become major pest in the recent past in cotton growing areas of Karnataka (Patil et al. 2006) and mealy bug has been reported as one of severe pests on $B t$ cotton from different parts of the country.

In this regard, it is presumed that some of the factors attributed to farmers' cotton yield is associated with the utilization of pesticides and socio-economic conditions prevailing among cotton farmers. This study provides an insight into socio-economic conditions and attitude of farmers towards pesticide use. Results of the study would be useful to both policy makers and farmers of the region in understanding the impact of pesticide use.

\section{Methodology}

During 2014-15, cotton was grown to an extent of 8.75 lakh hectare with 23.12 lakh bales of production and 1,793 metric tonne of pesticide consumption in Karnataka. Dharwad district of Karnataka occupying an area of 90,497 ha under cotton was purposively selected. Three taluksi. eNavalgund, Kundagol and Hubli were selected based on maximum area under cotton cultivation.
Two villages from each taluk were selected based on the highest number of cotton farmers and maximum area under cotton. Twenty cotton farmers from each village were post stratified into small, medium and large farmers proportionately making a total sample of 120. The farmers having land holdings of less than two hectares were grouped as small farmers while, more than two and less than four hectares were grouped as medium farmers and more than four hectares were grouped as large farmers. Primary data on various aspects of sample farmers for 2016-17 agricultural year was collected through field survey by the interview and recall memory method with the help of a pre-tested and wellstructured schedule in the month of November and December 2016. Simple averages and percentages were calculated for tabulation of the collected data.

\section{RESULTS AND DISCUSSION}

\section{General characteristics of the sample farmers}

The perusal of Table 1 reveals that 44.16 percent of the sample farmers were in old age groups $(>50$ years). The average age of sample farmers was 54.57 years. Hence it may be inferred that old aged group have interest towards adoption of new technologies in farming.

The analysis of education level of sample respondents showed that farmers studied in high school were 38.33 per cent and illiterates were about 16.66 per cent. Majority of small and medium farmers possessed education up to high school level, whereas large farmers had higher level of education. Thus, it is apparent from the results that the education levels of medium and large farmers were high as compared to that of small farmers because they were observed to have better financial position.

Further perusal of Table 1 reveals that average family size of sample farmers was 7 (6.59) which composed of two males, two females and three children. It was further noticed that around 35 small farmers belonged to nuclear type of family. This might be due to their attitude regarding the increased cost of living and difficulties in maintenance of big families.

The occupational pattern of sample farmers is also presented in Table 1 that shows that agriculture was the only occupation among 84 farmers (i.e. 70\%). Livestock rearing was the most popular subsidiary 
Table 1: General characteristics of sample farmers

\begin{tabular}{|c|c|c|c|c|c|}
\hline S1. No. & Particulars & $\begin{array}{l}\text { Small farmers } \\
(\mathrm{n}=40)\end{array}$ & $\begin{array}{l}\text { Medium farmers } \\
\qquad(\mathrm{n}=40)\end{array}$ & $\begin{array}{l}\text { Large farmers } \\
\quad(n=40)\end{array}$ & $\begin{array}{c}\text { Total farmers } \\
(\mathrm{N}=120)\end{array}$ \\
\hline \multirow[t]{6}{*}{1} & Age & & & & \\
\hline & Young age (<35 years) & $15(12.50)$ & $10(8.33)$ & $6(5.00)$ & $31(25.83)$ \\
\hline & Middle age (35-50 years) & $12(10.00)$ & $15(12.50)$ & $9(7.50)$ & $36(30.00)$ \\
\hline & Old age (>50 years) & $13(10.83)$ & $15(12.50)$ & $25(20.83)$ & $53(44.16)$ \\
\hline & Average age (years) & 44.41 & 53.95 & 65.37 & 54.57 \\
\hline & Standard deviation & 15.37 & 9.84 & 10.35 & 13.13 \\
\hline \multirow[t]{6}{*}{2} & Educational status & & & & \\
\hline & Illiterate & $10(8.33)$ & $6(5.00)$ & $4(3.33)$ & $20(16.66)$ \\
\hline & Primary school & $9(7.50)$ & $12(10.00)$ & $13(10.83)$ & $34(28.33)$ \\
\hline & High school & $16(13.33)$ & $15(12.50)$ & $15(12.50)$ & $46(38.33)$ \\
\hline & College & $4(3.33)$ & $5(4.16)$ & $5(4.16)$ & $14(11.66)$ \\
\hline & Graduate & $1(0.83)$ & $2(1.16)$ & $3(2.50)$ & $6(5.00)$ \\
\hline \multirow[t]{5}{*}{3} & Family composition & & & & \\
\hline & Average Family size & $5.83(100)$ & $6.63(100)$ & $7.31(100)$ & $6.59(100)$ \\
\hline & Average Male & $2.01(34.47)$ & $2.48(37.40)$ & $2.63(35.97)$ & $2.37(35.96)$ \\
\hline & Average Female & $1.65(26.70)$ & $1.85(26.70)$ & $1.78(26.70)$ & $1.76(26.70)$ \\
\hline & Average Children & $2.17(37.22)$ & $2.30(34.96)$ & $2.90(39.67)$ & $2.46(37.32)$ \\
\hline \multirow[t]{3}{*}{4} & Type of family & & & & \\
\hline & Nuclear & $35(29.16)$ & $29(24.16)$ & $24(20.00)$ & $88(73.33)$ \\
\hline & Joint & $5(4.16)$ & $11(9.16)$ & $16(13.33)$ & $32(26.66)$ \\
\hline \multirow[t]{5}{*}{5} & Occupation & & & & \\
\hline & Agriculture & $25(20.83)$ & $28(23.33)$ & $31(25.83)$ & $84(70.00)$ \\
\hline & Agriculture + Agriculture labour & $7(5.53)$ & $5(4.16)$ & - & $12(10.00)$ \\
\hline & Agriculture + Livestock & $2(1.16)$ & $3(2.50)$ & $8(7.50)$ & $13(10.83)$ \\
\hline & Agriculture + Others & $6(5.00)$ & $4(3.33)$ & $1(0.83)$ & $11(9.16)$ \\
\hline
\end{tabular}

Note: Figures in parentheses indicate percentage to the total.

enterprise along with agriculture among 10.53 per cent farmers. Agriculture with other jobs like petty business, grocery, tractor driving etc was observed among 9.16 per cent farmers, mostly small farmers, which might be due to their small holdings and seasonality in agriculture.

\section{Land holding}

The average size of land holding of small, medium and large farmers was found to be 1.24, 2.86 and 6.73 ha respectively with an overall average of $3.61 \mathrm{ha}$, as shown in Table 2 . The average size of irrigated farm was 0.74 ha. Medium and large farmers respectively had 0.59 and 0.88 ha under irrigation.

\section{Cost and returns structure of farmers in cotton cultivation}

The cost and returns from cotton cultivation were calculated and presented in Table 3. Among the three different farm size groups, the per hectare total cost incurred by large farmers was highest ( $₹ 52,825.37)$ as compared to medium and small farmers (₹ 51,574.6 and ₹ 50,766.27), respectively. The cost of human labour, seed, fertilizer and tractor labour accounted major share in the variable costs in case of large farmers, because these are major inputs and most of the operations like harvesting/ picking, spraying and weeding are labour intensive. This may be attributable to the fact that large farmers have more variable and fixed costs than their counterparts. The gross returns obtained per hectare by large farmers were high (₹ 95,690.89). The net returns per hectare obtained by large farmers was high (₹ 42,825.52) as compared to medium farmers (₹ 40,299.60) and small farmers (₹ 39,384.04). The average yield of cotton was $17.60 \mathrm{q} / \mathrm{ha}$. The yield 
Table 2: Average land holdings of sample farmers (ha)

\begin{tabular}{cccccc}
\hline S1. No. & Particulars & $\begin{array}{c}\text { Small farmers } \\
\mathbf{n = 4 0}\end{array}$ & $\begin{array}{c}\text { Medium farmers } \\
\mathbf{n = 4 0}\end{array}$ & $\begin{array}{c}\text { Large farmers } \\
\mathbf{n}=\mathbf{4 0}\end{array}$ & $\begin{array}{c}\text { Total farmers } \\
\mathbf{N}=\mathbf{1 2 0}\end{array}$ \\
\hline 1 & Dry land & 1.24 & 2.27 & 5.30 & 2.93 \\
2 & Irrigated land & -- & 0.59 & 0.88 & 0.73 \\
3 & Land on rent & -- & -- & 0.55 & 0.55 \\
4 & Total land holdings & 1.24 & 2.86 & 6.73 & 3.61 \\
5 & Total operational land holding & 1.24 & 2.86 & 6.18 & 3.42 \\
\hline
\end{tabular}

Table 3: Cost of cultivation of cotton of sample farmers (₹/ha)

\begin{tabular}{|c|c|c|c|c|c|c|}
\hline S1. No. & Particulars & $\begin{array}{l}\text { Small farmers } \\
n=40\end{array}$ & $\begin{array}{c}\text { Medium } \\
\text { farmers } n=40\end{array}$ & $\begin{array}{c}\text { Large farmers } \\
\quad \mathrm{n}=40\end{array}$ & $\begin{array}{l}\text { Total farmers } \\
\qquad \mathrm{N}=120\end{array}$ & $\begin{array}{l}\text { Per cent to } \\
\text { the total }\end{array}$ \\
\hline 1 & Human labour & $12,304.60$ & $12,566.40$ & $13,149.40$ & $12,673.47$ & 24.49 \\
\hline 2 & Bullock labour & 3379.55 & 3116.34 & 2705.74 & 3067.21 & 5.92 \\
\hline 3 & Machine labour & 3304.69 & 4223.13 & 4331.87 & 3953.23 & 7.64 \\
\hline 4 & Seeds & 5081.78 & 5096.02 & 5176.68 & 5118.16 & 9.89 \\
\hline 5 & Fertilizer & 4418.73 & 4457.96 & 4482.92 & 4453.20 & 8.60 \\
\hline 6 & FYM & 5000 & 5000 & 5000 & 5000 & 9.66 \\
\hline 7 & Pesticides & 5192.61 & $4,947.93$ & 5019.49 & 5053.34 & 9.76 \\
\hline \multirow[t]{2}{*}{8} & Interest on working capital@7\% & 1992.17 & 1910.13 & 1757.32 & 1886.54 & 3.64 \\
\hline & Total variable costs & $40,674.12$ & $41,317.91$ & $41,623.62$ & $41,205.15$ & 79.65 \\
\hline 9 & $\begin{array}{c}\text { Depreciation on Implements \& Farm } \\
\text { Building }\end{array}$ & 962.73 & 1003.29 & 1943.86 & 1303.29 & 2.51 \\
\hline 10 & Land revenue and taxes & 60.45 & 60.45 & 60.45 & 60.45 & 0.11 \\
\hline 11 & Rental value of land & 8333.33 & 8333.33 & 8333.33 & 8333.33 & 16.10 \\
\hline \multirow[t]{9}{*}{12} & Interest on fixed capital@12\% & 735.63 & 859.67 & 904.31 & 833.20 & 1.61 \\
\hline & Total fixed costs & $10,092.14$ & $10,256.74$ & $11,241.95$ & $10,530.28$ & 20.35 \\
\hline & Total costs & 50,766 & 51,575 & 52,865 & 51,735 & 100.00 \\
\hline & Yield(q) & 17.37 & 17.55 & 17.90 & 17.60 & \\
\hline & Cost of production (₹/q) & 2923 & 2939 & 2953 & 2938 & \\
\hline & Total output/Gross returns & 90,150 & 91,874 & 95691 & 92,572 & \\
\hline & Net returns & 39,384 & 40,300 & 42,826 & 40,836 & \\
\hline & Net returns $(₹ / q)$ & 2267 & 2296 & 2392 & 2319 & \\
\hline & Returns to investment ratio & 1.77 & 1.78 & 1.81 & 1.79 & \\
\hline
\end{tabular}

Table 4: Cost of pesticide application among different farm sizes (per ha)

\begin{tabular}{cccccc}
\hline S1. No. & Cost of pesticides (₹) & $\begin{array}{c}\text { Small farmers } \\
\mathbf{n}=\mathbf{4 0}\end{array}$ & $\begin{array}{c}\text { Medium farmers } \\
\mathbf{n = 4 0}\end{array}$ & $\begin{array}{c}\text { Large farmers } \\
\mathbf{n = 4 0}\end{array}$ & $\begin{array}{c}\text { Total farmers } \\
\mathbf{N}=\mathbf{1 2 0}\end{array}$ \\
\hline 1 & $2500-3500$ & $3(2.50)$ & $7(5.83)$ & $7(5.83)$ & $17(14.16)$ \\
2 & $3500-4500$ & $7(5.83)$ & $10(8.33)$ & $13(10.83)$ & $30(25.00)$ \\
3 & $4500-5500$ & $23(19.16)$ & $17(14.16)$ & $14(11.16)$ & $54(45.00)$ \\
4 & $5500-6500$ & $5(4.16)$ & $5(4.16)$ & $4(3.33)$ & $14(11.66)$ \\
5 & $>6500$ & $2(1.66)$ & $1(0.83)$ & $2(1.66)$ & $5(4.16)$ \\
\hline
\end{tabular}

Note: Figures in parentheses indicate percentage to the total.

of cotton was highest in case of large farmers being $17.90 \mathrm{q} /$ ha as compared to medium (17.55 q/ha) and small farmers (17.37 q/ha). This was due to better output price realization by them than by their other counterparts because they were found to be more educated and aware of market prices. 
Labour expense was the major component of variable cost while rental value of land was the major fixed cost. Similar results were found with Murthy (2015) that among the three different farm size farmers, the total cost incurred by medium farmers was the highest (₹ 21023.39/acre) and the benefit cost ratio was high in case medium farmers (1.72) followed by small farmers (1.61) and marginal farmers (1.58).

The pesticides shared 9.76 per cent of the total cost of cultivation of cotton. It was noticed that the per hectare expenditure on pesticide was highest for small farmers (₹ 5192.61) as compared to large (₹ $5019.49)$ and medium farmers (₹ 4,947.93). Small farmer's feared more of crop loss, so spent more on pesticides. Subbharao et al. (1987) indicated that in cotton growing region of Guntur districts of Andhra Pradesh, the pesticide expenditure was 20 to 25 per cent of the total cost. Birthal et al. (2000) indicated that farmers spent 29 per cent expenditure on pesticides over the total costs.

Across the farm groups, there was not much noticeable difference in different component of costs. Similar results were reported by Gamanagati et al. (2012) and Mahendra and Chandershekara (2007).

Cost of pesticide application among different farm sizes per hectare is presented in Table 4. Cost of pesticide ranges from ₹ 2500 to more than ₹ 6500 . The range of ₹ 4500- ₹ 5500 was highest in case of 54 farmers $(45.00 \%)$, mostly small farmers, even though farmers lack funds, they had spent more on pesticides to protect the crop. Farmers in the group more than ₹ 6500 were less in number i.e. 4.16 per cent to the total. Santkumar and Dhandapani (2000) in his study indicated that cotton crop in Nanded district of Maharashtra was treated with PPCs eight times during its production cycle.

\section{Farmer's opinion towards Pesticide use}

About 37.50 per cent farmers reported that the level of pesticide usage was insufficient to control the pests. It was noticed 23.33 per cent of farmers were reading the instructions on pesticide container, to know the quantity of pesticide use and precautions to be taken and treatment for accidental poisoning only which is presented in the Table 5. Similar results were found with Devi (2009) that about two-thirds (63 per cent) of the farm workers knew that pesticides with different levels of toxicity were available in the market. But, almost all of them (99.5 per cent) could not understand the toxicity level after reading the colour code on the bottles. The workers often related the toxicity of pesticides to the odour of the chemical and more pungent ones were considered as more toxic. The scientific categorization based on colour code was rarely understood.

\section{Pesticide Handling Practices}

The pesticide handling practices followed by sample farmers is presented in Table 6. It is astonishing to notice that about 73.33 per cent of the farmers were not using protective coverings during pesticide application and most of them were small farmers. This was mainly due to their laziness and uncomfortable feeling while spraying. This increased the probability of exposure to pesticide poisoning and health hazards. About 40 per cent of farmers took bath after spraying, while 60 per cent ignored it. Table 6 also reveals that 58.33 per cent of farmers apply the pesticide without considering wind direction which is not the correct method and

Table 5: Farmers' opinion towards pesticide use

\begin{tabular}{|c|c|c|c|c|c|}
\hline \multirow[b]{2}{*}{ S1. No. } & \multirow[b]{2}{*}{ Particulars } & \multicolumn{4}{|c|}{ Farmers reported } \\
\hline & & $\begin{array}{c}\text { Small } \\
\mathrm{n}=40\end{array}$ & $\begin{array}{c}\text { Medium } \\
\mathrm{n}=40\end{array}$ & $\begin{array}{c}\text { Large } \\
\mathrm{n}=40\end{array}$ & $\begin{array}{c}\text { Total } \\
\mathrm{N}=120\end{array}$ \\
\hline 2 & Insufficient use of pesticide & $10(8.33)$ & $16(13.33)$ & $19(15.83)$ & $45(37.50)$ \\
\hline 3 & Awareness about prices of alternate pesticides & $14(11.66)$ & $8(6.66)$ & $11(9.16)$ & $33(27.50)$ \\
\hline
\end{tabular}

Note: Figures in parentheses indicate percentage to the total. 
Table 6: Pesticide handling practices followed by sample farmers

\begin{tabular}{|c|c|c|c|c|c|}
\hline \multirow[b]{2}{*}{ Sl. No. } & \multirow[b]{2}{*}{ Particulars } & \multicolumn{4}{|c|}{ Farmers reported } \\
\hline & & $\begin{array}{l}\text { Small farmers } \\
\qquad \mathrm{n}=40\end{array}$ & $\begin{array}{c}\text { Medium } \\
\text { farmers } n=40\end{array}$ & $\begin{array}{l}\text { Large farmers } \\
\qquad \mathrm{n}=40\end{array}$ & $\begin{array}{l}\text { Total farmers } \\
\qquad \mathrm{N}=120\end{array}$ \\
\hline \multirow[t]{6}{*}{1} & Safety measures & & & & \\
\hline & 1. No protective measures followed & $33(27.50)$ & $31(25.83)$ & $24(20.00)$ & $88(73.33)$ \\
\hline & 2. Use of face masks & $3(2.50)$ & $4(3.33)$ & $6(5.00)$ & $13(10.83)$ \\
\hline & 3. Use of hand gloves & $6(5.00)$ & $5(4.166)$ & $7(5.83)$ & $18(15.00)$ \\
\hline & 4. Use of shoes & - & $3(2.50)$ & $3(2.50)$ & $6(5.00)$ \\
\hline & $\begin{array}{l}\text { 5. Use of polythene bag instead of hand } \\
\text { gloves }\end{array}$ & $12(10.00)$ & $9(7.50)$ & $7(5.83)$ & $28(23.33)$ \\
\hline 2 & Taking bath after spraying & $18(15.00)$ & $17(14.16)$ & $13(10.83)$ & $48(40.00)$ \\
\hline \multirow[t]{4}{*}{3} & Washing hands after spray & & & & \\
\hline & (a) with soap & $18(15.00)$ & $15(12.50)$ & $20(16.66)$ & $53(44.16)$ \\
\hline & (b) with mud & $12(10.00)$ & $13(10.83)$ & $9(7.50)$ & $34(28.33)$ \\
\hline & (c) only water & $10(8.33)$ & $12(10.00)$ & $11(9.16)$ & $33(27.50)$ \\
\hline \multirow[t]{3}{*}{4} & Direction of application & & & & \\
\hline & Not considering wind direction & $27(22.50)$ & 23(19.16) & $20(16.66)$ & $70(58.33)$ \\
\hline & Along wind direction & $13(10.83)$ & $17(14.16)$ & $20(16.66)$ & $50(41.66)$ \\
\hline \multirow[t]{4}{*}{5} & Time of application & & & & \\
\hline & Morning & $30(25.00)$ & $24(20.00)$ & $28(23.33)$ & $82(68.33)$ \\
\hline & Afternoon & $7(5.83)$ & $8(6.66)$ & $10(8.33)$ & 23(19.16) \\
\hline & Evening & $3(2.50)$ & $8(6.66)$ & $2(1.66)$ & $15(12.50)$ \\
\hline \multirow[t]{4}{*}{6} & Pesticide mixing practice & & & & \\
\hline & Use wooden stick & $32(26.66)$ & $29(24.16)$ & $27(22.50)$ & $88(73.33)$ \\
\hline & By pouring water and spray lancer & $4(3.33)$ & $8(6.66)$ & $13(10.83)$ & $25(20.83)$ \\
\hline & Hands covered with plastic bag & $6(5.00)$ & $1(0.83)$ & - & $07(5.83)$ \\
\hline \multirow[t]{3}{*}{7} & Measurement of pesticide & & & & \\
\hline & Measuring jar & $31(25.83)$ & $28(23.33)$ & $36(30.00)$ & $95(79.16)$ \\
\hline & Bottle cap & $9(7.50)$ & $12(10.00)$ & $4(3.33)$ & $25(20.83)$ \\
\hline \multirow[t]{3}{*}{8} & Activities during application & & & & \\
\hline & Farmers chewing tobacco & $21(17.50)$ & $18(15.00)$ & 19(15.83) & $58(48.33)$ \\
\hline & Farmers smoking & $11(9.16)$ & $14(11.66)$ & $17(14.16)$ & $42(35.00)$ \\
\hline \multirow[t]{3}{*}{9} & Washing of spraying equipments & & & & \\
\hline & Yes & $16(13.33)$ & $12(10.00)$ & $27(22.50)$ & $55(45.83)$ \\
\hline & No & $24(20.00)$ & $28(23.33)$ & $13(10.83)$ & $65(54.16)$ \\
\hline \multirow[t]{4}{*}{10} & Disposal of left pesticide spray & & & & \\
\hline & In field & $32(26.66)$ & $18(15.00)$ & $20(16.66)$ & $70(50.00)$ \\
\hline & In irrigation channel & - & $8(6.66)$ & 17(14.16) & 25(29.16) \\
\hline & On road or bunds & $8(6.66)$ & 14(11.66) & $3(2.50)$ & $25(20.83)$ \\
\hline \multirow[t]{4}{*}{11} & Disposal of pesticide bottles & & & & \\
\hline & Left in field & $8(6.66)$ & $15(12.50)$ & 19(15.83) & $42(35.00)$ \\
\hline & Sold to junk dealers & $22(18.33)$ & $18(15.00)$ & $16(13.33)$ & $56(46.66)$ \\
\hline & Used for other purposes & $10(8.33)$ & $7(5.83)$ & $5(4.16)$ & $22(18.33)$ \\
\hline
\end{tabular}

Note: Figures in parentheses indicate percentage to the total.

there may be chances of inhaling chemicals and pesticide drift.

Regarding mixing of pesticides with water, 73.33 per cent of farmers used wooden stick to protect themselves from exposure to pesticides. For measurement of pesticides, most of the farmers
(79.16 per cent) used measuring jar while 20.83 per cent of farmers used the bottle cap.

The number of farmers who chew tobacco and smoke during pesticides application were about 48.33 per cent and 35.00 per cent respectively. Similar results by Arun Kumar (1995), his study 
reported that 7.5 per cent of farmers undertake chewing of tobacco and 3.3 per cent smoking during pesticide application.

About 54.16 per cent of the farmers do not wash the spraying equipments after use. With regard to left over pesticide spray in the sprayer, about 50.0 per cent farmers sprayed again into the field or let it into irrigation channels or roads or bunds. Thirty five per cent of sample farmers were leaving their pesticide containers in the field itself. This will lead to soil contamination destroying beneficial micro fauna and farmers are unaware of the negative consequences of pesticides on soil health. While 46.66 per cent of farmers sold the empty containers to junk dealers and 18.33 per cent used them for other purposes.

Similar results were found by Pinyupa et al. (2009) that more than half of the farmers used at least one kind of personal protection while handling pesticides. Interestingly, none of the farmers completely protected themselves, especially the respiratory system, head, eyes and hands, which should all be protected according to the concept of personal protective equipment.

\section{CONCLUSION}

The data pertaining to socioeconomic status revealed that old aged farmers have more interest towards adoption of new technologies in farming. The education levels of medium and large farmers were high as compared to that of small farmers because of their better financial position. Majority of the farmers belonged to medium size and nuclear type of family. The total costs, yield and returns were the highest per ha for large farmers. Most of the farmers (45\%) spent around ₹ 4500- ₹ 5500 for pesticides in cotton cultivation. The paper represents the condition of small farmers becoming the victims of pesticide use. Even though farmers lack funds, they had spent more on pesticides to protect the crop as the farmers had risk aversive nature to crop loss. In this study, pesticide use decreased with increase in size of land holding. The decision to spend money on pesticides should be economic threshold of pest infestation. The cotton farmers are not aware of the toxic residues of pesticides. Hence pesticide toxicity and their residual effects are to be highlighted by conducting trainings and meetings with farmers.

\section{REFERENCES}

Agro chemical report. Next generation Indian agriculture - Role of crop protection solutions a report on Indian agrochemical industry; 2016.

Arun Kumar, V.K. 1995. Externalities in the use of pesticides: an economic analysis in cole crop. M. Sc. (Agri.) Thesis. University of Agricultural Sciences Bangalore.

Brithal Pratap, S., Sharma, D.P. and Santhkumar. 2000. Economics of integrated pest management: Evidence and issues. Indian J. Agric. Econ., 55: 10-15.

De, A., Bose, R., Kumar, A. and Mozumdar, S. 2014. Targeted delivery of pesticides using biodegradable polymeric nanoparticles. Springer India. e-Book.

Devi, P.I. 2009. Health risk perceptions, awareness and handling behaviour of pesticides by farm workers. Agricultural Economics Research Review, 22: 263-268.

Gamanagatti, P.B., Dodamani, M.T., Gaddi, G.M. and Menasinahal, A.S. 2012. Cost and returns in Bt cotton cultivation across different farm sizes in northern Transitional Zone, Karnataka. Int. J. Agric. Sci., 8(2): 431-435.

Mahendra Dev, S. and N. Chandrasekhara, R. 2007. Socioeconomic impact of Bt cotton. CESS Monograph No. 3; 2007.

Murthy, C., Vilas, K. and Bouramma, P.K. A study on economic analysis of cotton production in North Karnataka. International Research Journal of Agricultural Economics and Statistics, 6(2): 419-425.

Santkumar and Dhandapani. 2000. Pesticide use in rainfed cotton frequency intensity and determinants. Agric. Econ. Res. Rev., 13(2): 107-122.

Subbharao, D.V., Chowdry, K.R. and Venkata Reddy, C.G. 1987. Degradation of agro-ecosystem- An explainatory study on cotton farming. Indian J. Agric. Econ., 42(3): p410-411.

Patil, B.V., Bheemanna, M., Patil, S.B., Udikeri, S.S. and Hosamani, A.C. 2006. Record of mirid bug Creontiades biseratense (Distant) on cotton from Karnataka, India. Insect Env., 11(4): 176-177.

Pinyupa, P., Kanchalee, Jand Sakchai, W. Pesticide use patterns among small-scale farmers: a case study from Phitsanulok, Thailand. Southeast Asian Journal Tropical Med. Public Health, 40(2): 401-410.

Sagar, D.C., Rayappa, B., Shasikant, U.S. and Bheemanna, M. 2013. Insecticide usage pattern in major Bt cotton growing districts of Karnataka, India. Journal of Experimental Zoology, 16(2): 461-466.

Shetty, P.K., Hiremath, M.B., Murugan, M. and Nerli, R.B. 2011. Farmer's health externalities in pesticide use predominant regions in India. World Journal of Science and Technology, 1(4): 01-11.

Singh, R. and Jaglan, R.S. 2005. Development and management of insecticide resistance in cotton whitefly and leafhoppera review. Agric. Rev., 26: 229-234. 
